\title{
Establishment and Optimization of Expression Synthetic Gene Using Recombinant 1B Capsid Protein of FMDV
}

\author{
Omar A. Omar ${ }^{1 *}$, Reda salem ${ }^{1}$, Hoda A. S. El-garhy² and Mahmoud m. A. Moustafa ${ }^{2}$ \\ ${ }^{1}$ Molecular Plant Biology Department, Agricultural Genetic Engineering Research Institute (AGERI), ARC, \\ 12619, Giza, Egypt \\ ${ }^{2}$ Genetics and Genetic Engineering Department, Faculty of Agriculture, Benha University, Egypt \\ Corresponding author: hoda.algarhy@fagr.bu.edu.eg
}

\begin{abstract}
Foot-and-mouth disease (FMD) is an acute, highly contagious disease that infects cloven-hoofed animals. There are seven serotypes of FMD virus (FMDV), namely O, A, C, SAT1, SAT2, SAT3 and Asia1.Serotypes A, $\mathrm{O}$ and SAT2, are responsible for the epidemics in our country and we are selected SAT2 as model in this work. In this study we are discuss the influence of time and concentration of isopropyl- $\beta$-D-thiogalactoside (IPTG) for induction of the tac-promoter as a synthetically produced DNA promoter, in small-scale cultivations is well established for over gene expression using Synthetic gene of recombinant 1B Capsid Protein of FMDV. For this purpose, the 1B-coding sequence was modified and optimized to match the codon usage preference of E. coli. The modified 1B-coding sequence was synthesize, amplification and cloning to construct of1B-PGEX4T1 bacterial expression vector and transformation in to E. coli BL21 (DE3) strain as expression host induction of the gene led to expression of the target protein. It is worthy that the best condition for 1B protein expression was $0.1 \mathrm{mM}$ IPTG at $16^{\circ} \mathrm{C}$ for overnight incubation. The expressed protein was analyzed by SDS-PAGE and the presence of a band with a molecular mass of approximately $53 \mathrm{KDa}$ (the expected size for the GST tagged protein $26 \mathrm{KDa}$ and 1B recombinant protein $22 \mathrm{KDa}$ ) and the yield of recombinant $1 \mathrm{~B}$ protein was $1 \mathrm{mg} / 100 \mathrm{ml}$ of culture medium.
\end{abstract}

Keywords: PCR, Recombinant DNA, Cloning, Expression, FMDV

\section{Introduction}

Foot-and-mouth disease virus (FMDV) is the causative agent of a highly contagious and economically devastating disease of cloven-hooved domestic and wild animals. It can cause a high number of deaths among young animals and production losses in adults and is the single most limiting constraint to international trade of live animals and animal products. FMDV belongs to the genus Aphthovirus in the family Picornaviridae and possesses a single strand of positive-sense RNA genome (Knowles NJ, Samuel AR, 2003). There are seven serotypes of the virus known as serotypes A, O, C, SAT1, SAT2, SAT3, and Asia1; each serotype includes several strains. The developed immunity after infection with one serotype has no protective effect against any other serotype (OIE, 2009). The main clinical signs of the disease are vesicular eruptions in the oral cavity, foot and udder; these lesions are associated with fever, lameness, salivation and anorexia (Grubman and Baxt, 2004).

The overexpression of plasmid-encoded genes is an important requirement for the development of processes with recombinant microorganisms. Overexpression depends on controlled promoter systems allowing separation of cell growth and product formation into two consecutive phases. However, only few of the known strong promoters are suitable for application in large scale processes. For this purpose, the PL and PR promoters of the bacteriophage lambda or the promoter can be used
(Jung et al. 1988; Shimizu et al. 1987). Another group of commonly used systems in controlled gene expression is the lac promoter and its fusion products (tac, pac, rat). They are induced by isopropyl- $\beta$-Dthiogalactoside (IPTG) very easily and effectively. The advantages of the tac promoter could be demonstrated in high cell density processes (Lee et al. 1989; Chalmers et al. 1990).

\section{Materials and Methods}

\section{Amplification of -1B-CP-Gene \\ Two oligonucleotide primers, sense, 5'- GGATCCACCACCACAAGCACCACC-3', and the anti-sense,} 5'- CTCGAGATTACG GCAGTTCACCC-3')

flanked BamHI and salI recognition sequences respectively for subsequent cloning were designed were used for PCR amplification of 1B-CP-ORF gene based on the published sequence of Egyptian SAT-2 isolate ( $\mathrm{gb} \mid \mathrm{AAZ} 83686)$. PCR was conducted in a volume of $50 \mu \mathrm{l}$ containing, $1 \mathrm{X}$ reaction buffer with MgSO4, $200 \mu \mathrm{M}$ each dNTPs (dATP, dTTP, dCTP and dGTP), 0.4 pmol of each primer, 0.025 units of Pfu DNA polymerase, template and d.d. $\mathrm{H}_{2} \mathrm{O}$. PCR was performed in a Perkin-Elmer (Gene Amp PCR System 2400) for 35 cycles after initial denaturation for $10 \mathrm{~min}$ at $95^{\circ} \mathrm{C}$. Each cycle consisted of denaturation at $95^{\circ} \mathrm{C}$ for $35 \mathrm{sec}$, annealing at $55^{\circ} \mathrm{C}$ for $1 \mathrm{~min}$, extension at $72^{\circ} \mathrm{C}$ for $1 \mathrm{~min}$. The primer extension was extended to $7 \mathrm{~min}$ at $72^{\circ} \mathrm{C}$ in the final cycle. Amplified fragment of the $-1 \mathrm{~B}-\mathrm{CP}-$ gene 
separated using $1.2 \% \quad(w / v)$ agarose gel electrophoresis. The PCR amplified product was detected by electrophoresing on $1.2 \%$ agarose gel in 1X TAE buffer at 80 volts for one hour (Sambrook, et al, 1989). Tailing and purification of amplified 1BCP-gene. Where Post PCR amplification, $25 \mu \mathrm{l}$ from the PCR product was heated at $95^{\circ} \mathrm{C}$ for $20 \mathrm{~min}, 7.5$ $\mu \mathrm{ldATP}$ (from a $2 \mathrm{mM}$ stock), $1.5 \mu \mathrm{MgCl} 2$ (from a stock $50 \mathrm{mM})$ and $1 \mu \mathrm{l}(0.5$ Unit) of Taq DNA polymerase were added, and the mixture was incubated at $70^{\circ} \mathrm{C}$ for $15 \mathrm{~min}$.

\section{Cloning and transformation}

A-tailed PCR fragment was ligated into the pGEM-T easy vector in a volume of $20 \mu \mathrm{l}$. The ligation reaction was performed by adding $5 \mu \mathrm{l}$ of $2 \mathrm{X}$ rapid ligation reaction buffer, $1 \mu$ lpGEM-T easy vector $(50 \mathrm{ng}), 3 \mu \mathrm{l}$ of A-tailed PCR product, $1 \mu \mathrm{l}$ of T4 DNA ligase (3 Weiss units/ $\mu \mathrm{l}$ ) and $10 \mu \mathrm{l}$ d.d. $\mathrm{H}_{2} \mathrm{O}$. The mixture was mixed by pipetting and incubated for $1 \mathrm{~h}$ at room temperature. The competent cells of E. coli (strain JM 109) were prepared using $\mathrm{CaCl} 2$ as described by (Hammond and Hammond, 1989) and method of transformation was carried out as described by (Hanahan, and Meselson, 1983).Confirmation of recombinant plasmid Restriction digestion The Wizard® plasmid mini-preparation system from Promega was used to isolate pure super-coiled plasmid DNA with high yields. The PCR product was cloned intopGEM-T Easy vector to create the plasmid pOAR1(pGEMT easy vector +1B-ORF) that introduced into E. coli(strain JM 109). After minipreparation, the purified plasmid DNA was subjected to digestion with the restrictionendonucleases was performed as $1 \mu \mathrm{g}$ recombinant plasmid (RP) using the restriction endonucleases BamHI and SallI The reaction was performed in $20 \mu \mathrm{l}$ total volume, $10 \mathrm{X}$ fast digest buffer and $1 \mu \mathrm{l}$ of BamHI and XhoI each enzyme. The reaction was incubated at $37^{\circ} \mathrm{C}$ for $2 \mathrm{~h}$. The mixture was resolved by electropheresis in $1.2 \%$ agarose gel as mentioned previously.

\section{Expression of 1B- Gene Using PGEX System}

A according to the manual instructions of GST Gene Fusion System Handbook (GE Healthcare life Science), the positive clone was digested with BamHI and Sall restriction endonuclease enzymes and the released fragment was subcloned into PGEX4T1 vector that was previously digested with the same restriction enzymes, and the obtained plasmid designated pOAR2. After ligation, plasmid was transformed into E.coli strain BL21. The recombinant plasmid was screened under two different concentrations from IPTG (1 and $0.1 \mathrm{mM})$ at different incubation times $(1,2,3,4 \mathrm{hr}$ and overnight respectively at $37^{\circ} \mathrm{C}$ and $\left.16^{\circ} \mathrm{C}\right)$. Five $\mathrm{ml}$ of $\mathrm{LB}$ broth, containing ampicillin $(100 \mu \mathrm{g} / \mathrm{ml})$, were inoculated with a single colony from individual cultures of the host strain carrying the plasmid pOAR2 and PGEX$4 \mathrm{~T}-1$ vector (as a negative). The ampicillin free LB broth was also inoculated with untransformed host strain. All cultures were then incubated $\mathrm{O} / \mathrm{N}$ at $37^{\circ} \mathrm{C}$ with shaking at $150 \mathrm{rpm}$. Ten $\mathrm{ml}$ of $\mathrm{LB}$ broth, containing ampicillin $(100 \mu \mathrm{g} / \mathrm{ml})$ was inoculated with $1 \mathrm{ml}$ of $\mathrm{O} / \mathrm{N}$ grown cultures. Ampicillin was omitted from culture inoculated with untransformed bacterial cells. The individual cultures were incubated at $37^{\circ} \mathrm{C}$ with vigorous shaking at $250 \mathrm{rpm}$ until the OD600 nm reached $0.55-0.6$.The expression process was induced by adding IPTG in a final concentration of $1 \mathrm{mM}$ and $0.1 \mathrm{mM}$ to the cultures and re-incubated at $37^{\circ} \mathrm{C}$ and $16{ }^{\circ} \mathrm{C}$ with shaking. The level of protein expression was analyzed at different incubation times $(1,2$, and 3 $\mathrm{h}$ and overnight) to select the best concentration from IPTG and the suitable time of incubation. The bacterial cells were harvested by centrifugation in a microcentrifuge tube for $1 \mathrm{~min}$ at $14000 \mathrm{rpm}$. The supernatants were removed to other tubes and the cell pellets of the individual cultures were washed with d.d.H2O. One hundred micro liters of $1 \mathrm{X}$ sample loading buffer were added to each pellet and vortex to resuspend cells completely. Similarly, 1X sampling buffer was also added to the supernatants. Then the resuspended cells and supernatants were boiled for 5 min and immediately chilled on ice until required. The protein(s) was determined using $12 \%$ SDS-PAGE as described before.

\section{Result}

\section{PCR Amplification of $1 B-C P$ - gene}

The nucleotide sequence of the Egyptian SAT-2 isolate (gb|AAZ83686) was employed as a model system in this study. Two additional primers (1B -F and $1 \mathrm{~B}-\mathrm{R})$ were constructed with specific restriction site (BamHI and SalI) to amplify target gene of $1 \mathrm{~B}$ Coat protein Gene. The synthetic gene of 1B-CP-gene was used as a template in PCR and the amplified interested gene was 591 bp (Figure 1) showing PCR amplification of 1B-CP-gene. And were detected in both samples.

Fig (1): Agarose gel showing PCR amplification of

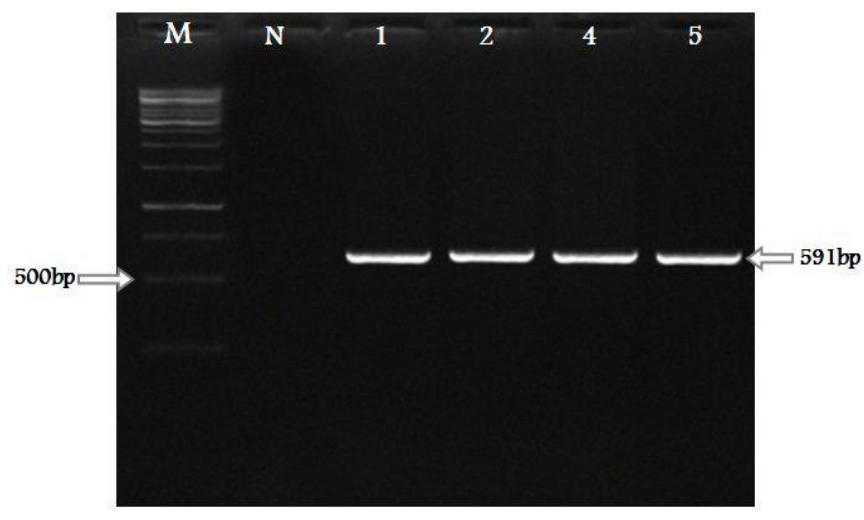

1B-CP coat protein gene. M: $1 \mathrm{kbp}$ DNA marker, Lanes from 1 to 5; represent PCR 
amplification using pGST-4T-1 Vector and Lane 6;represent negative control.

\section{Cloning of of $1 B-C P$-gene}

The dDNA PCR product was cloned into pGEM-T Easy vector to create the plasmid and putative clone was designated pOAR(Figure 2) Showed the recombinant plasmids released from the 6 selected colonies (one negative and 5 positive ligated colonies), recombination succeeded in all colonies belonging to the (pGEM-T easy vector $+1 \mathrm{~B}-\mathrm{CP}$ gene).five colonies were successfully transformed but only one colony failed due to self-ligation of plasmid (the plasmid was transferred into the cell but without 1B-CP gene. After mini-preparation, the purified plasmid DNAs were subjected to digestion with BamHI and SalI as a confirmatory test, a segment of about 591 bp (Figure 3) were released from all recombinant plasmids.

The released fragment was subcloned into PGEX4T1 vector that was previously digested with the same restriction enzymes, and the obtained plasmid designated pOAR (Figure 4). After transformation, 6 white colonies were selected and subsequently digested by BamHI and Sal I as a confirmative method that established the insertion of the recombinant plasmid including $1 \mathrm{~B}-\mathrm{CP}$ gene. These 6 selected colonies represented positive ligation the plasmid pOAR was transformed into E.coli BL 21.

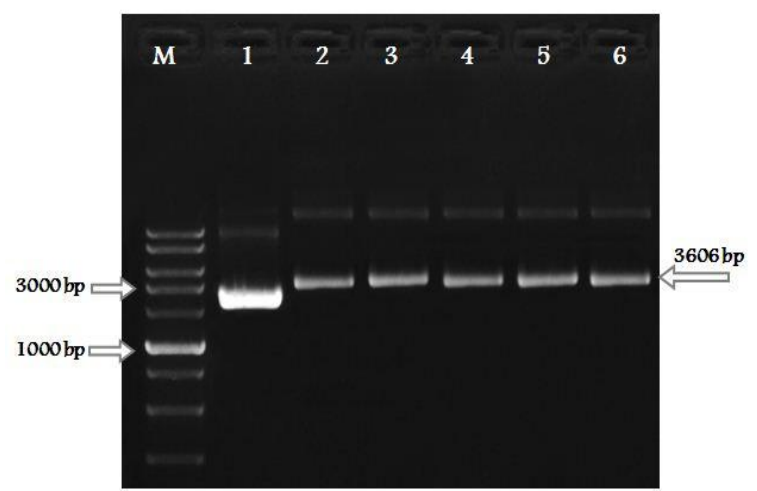

Fig 2. Plasmids miniprep for transformed stains $\mathbf{M}$; $1 \mathrm{~Kb}$ DNA marker, Lane 1; blue colony with no recombinant pOAR1 plasmid. Lanes from 2 to 6; represent the recombinant plasmids extracted from cells.

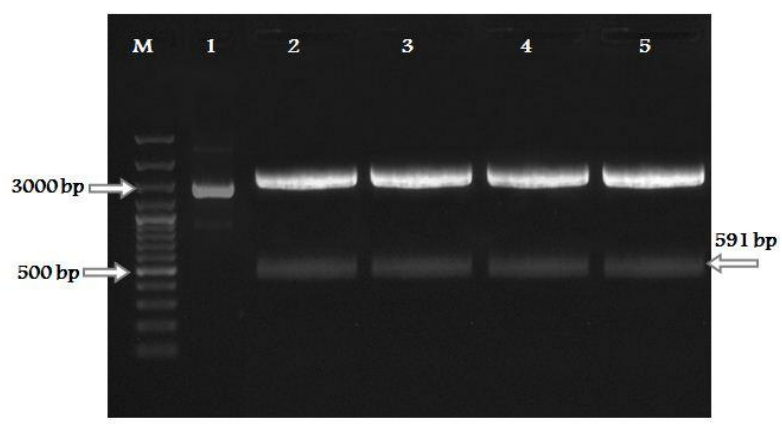

Fig 3. Digestion reaction of recombinant plasmids with BamHI\&SalI1. M: $1 \mathrm{~Kb}$ DNA marker. Lane 1; represent negative plasmid not digested Lanes: from 2 to 5; represent the released fragments from the recombinant plasmids extracted from strain.

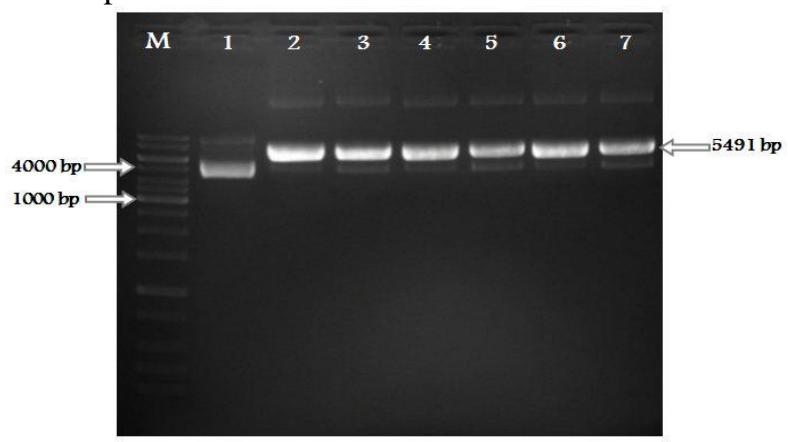

Fig 4. Plasmids miniprep for transformed stains $\mathbf{M}$; $1 \mathrm{~Kb}$ DNA marker, Lan1; negative control with no recombinant pOAR1 plasmid. Lanes from 2 to 7; represent the recombinant plasmids extracted from cells.

\section{Expression and Purification of $1 \mathrm{~B}-\mathrm{CP}$ - Gene}

The recombinant plasmid pOAR was transformed into E.coli BL21 (as an expression host). The expression process was induced by adding two different concentrations of IPTG $(0.1$ and $1.0 \mathrm{mM}$ for $1,2,3,4 \mathrm{~h}$ and overnight respectively at $37^{\circ} \mathrm{C}$ and $16^{\circ} \mathrm{C}$. To confirm the expression of the transformed 1B-CP gene, Fig (24): Shows protein pattern obtained by vector alone (expressed GST protein only) which represents lane (2), E.coli BL21 which represents lane (1) as compared to recombinant cells (congaing GST in addition to $1 \mathrm{~B}-\mathrm{CPgene}$.SDS-PAGE as exhibited the presence of ten polymorphic bands. Ten bands of protein $(70: 25 \mathrm{kDa})$ were detected in all lanes. A unique band of $26 \mathrm{kDa}$ (monomorphic band) was detected in lanes; this protein band belonged to GST protein expressed by pGEX plasmid.Likewise, the protein profile of E.coli BL21 strain containing the recombinant pOAR displayed the detection of 11 protein bands (100:15 kDa) in lanes (3-7). A band of $48 \mathrm{kDa}$ was detected representing the expression product of the recombinant including both 1BCPproteins fused to GST protein that means the protein fragment without GST fragment had a molecular weight of $22 \mathrm{kDa}$ (1B-CP protein). A band of $26 \mathrm{kDa}$. 

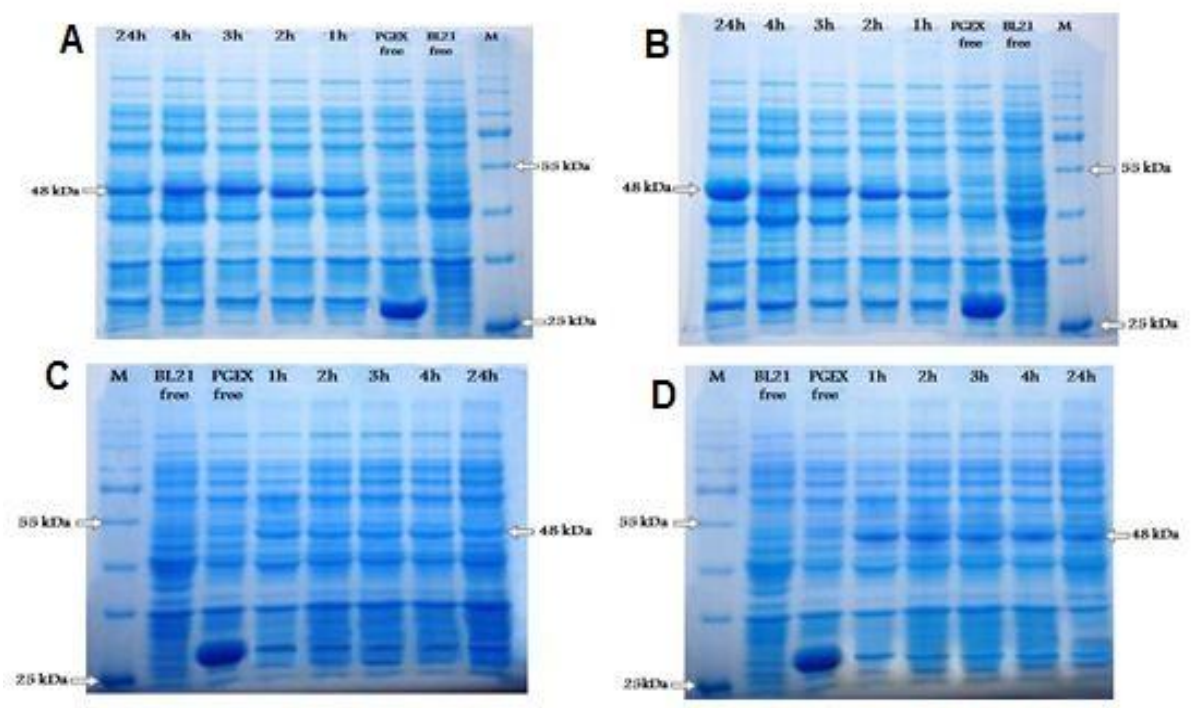

Fig5. SDS-PAGE of expresstion at different concentration of IPTG and tempreturewhere A $\left(0.1 \mathrm{mM} / 37^{\circ} \mathrm{C}\right), \mathrm{B}(0.1$ $\left.\mathrm{mM} / 16^{\circ} \mathrm{C}\right), \mathrm{C}\left(0.1 \mathrm{mM} / 37^{\circ} \mathrm{C}\right)$ and $\mathrm{D}\left(0.1 \mathrm{mM} / 1^{\circ} \mathrm{C}\right)$ M: protein marker, Lane BL21 free represents extract of $-\mathrm{ve}$ control. Lane PGEX free represents extract from expression cell containing PGEX plasmid, Lanes from 4 to 8: represent cell lysate of the strain harvested after 1,2, 3, 4 and 24h.

\section{Discussion}

FMD, one of the most devastating diseases of livestock, can cause significant economic losses worldwide, and remains the most important constraint to international trade in live animals and animal products. FMDV is divided into seven serotypes with no cross-protection conferred among the serotypes, and three of which exist in Egypt, including serotypes $\mathrm{O}$, A, and SAT2 FMDV serotype (Knowles NJ, Samuel AR, 2003). When the expression of foreign proteins in the microbial systems is challenging because these proteins generate metabolic burden to the host. Due to the foreignness, producing higher concentrations of soluble heterologous protein is a significant problem. Because these foreign proteins tend to misfold and form insoluble inclusions in the cytoplasm of the host(de Marco et al 2007).The IPTG concentration may have to be optimized for every protein under the conditions used. The fusion proteinstrategy gave a slightly lower total activity but the level of soluble recombinant protein obtained was in this case significantly less sensitive to the inducer concentration applied.Due to its significant homology, the 1B-coding sequence was sub-cloned in the pGex4t-1 expression vector and the recombinant1B-capsid protein expressed and induced by adding two different concentrations of IPTG $(0.1$ and $1.0 \mathrm{mM}$ for $1,2,3$, $4 \mathrm{~h}$ and overnight respectively at $37^{\circ} \mathrm{C}$ and $16^{\circ} \mathrm{C}$. After optimize the expression system to prepare antigenic recombinant protein. The best condition for $1 \mathrm{~B}$ protein expression was $0.1 \mathrm{mM}$ IPTG at $16^{\circ} \mathrm{C}$ for overnight incubation. The expressed protein was $53 \mathrm{KDa}$ (26
KDa represents GST tagged protein and $27 \mathrm{KD}$ represent $1 \mathrm{~B}$ recombinant protein) and the yield of recombinant $1 \mathrm{~B}$ recombinant protein was $1 \mathrm{mg} / 100 \mathrm{ml}$ of culture medium.Finally we are purified of 1B recombinant proteinaccording to a band of $48 \mathrm{kDa}$ that representing the expression product of the recombinant including both $1 \mathrm{~B}-\mathrm{CP}$ proteins fused to GST protein that means the protein fragment without GST fragment had a molecular weight of $22 \mathrm{kDa}$ (1BCP protein).

\section{Reference}

Chalmers, J.J; Shuler .ML;Wilson DB (1990) A simple membrane reactor to obtain high cell density and plasmid encoded protein production from Escherichia coli. Biotechnol Tech 4:73- 78

Giridharan, $\quad P ;$ Hemadri, $\quad$ D;Tosh ,C;Sanyal,A;Bandyopadhyay, S.A (2005). Development andevaluation of a multiplex PCR for differentiation offoot-and-mouth disease virus strains native to India.Journal of Virological Methods, 126: 1-1

Grubman, M.J. and Baxt, B. (2004) Foot-and-Mouth Disease. Clinical Microbiology Reviews, 17, $465-493$

de Marco ,A;Deuerling E;Mogk, A;

Tomoyasu,T;Bukau B (2007)Chaperone-based procedure to increase yields ofsolublerecombinant proteins produced in $\mathrm{E}$. coli. BMC biotechnol 7: 32 .

Hammond, J. \& R. W. Hammond (1989). "Molecular cloning, sequencing and expression in 
Escherichia coli of the bean yellow mosaic virus coat protein gene. Journal of General Virology 70:1961-1974

Hanahan, D\& M. Meselson (1983). "In Methods in Enzymology," Vol. 100, Wu.et al. (eds), Acad. Press. NY, p. 333

Jung, G;Den,fle, P;Becquart, J;Mayaux, J.F (1988) High-cell density fermentation studies of recombinant Escherichia coli strains expressing human interleukin-lfl. Ann Inst Pasteur/ Microbiol 139:129-146

Lee, J.H,; Choi, Y.H; Kang SK; Park HH;Kwon IB (1989) Production of human leukocyte interferon in Escherichia coli by control of growth rate in fed-batch fermentation. BiotechnolLett

OIE (2009). Terrestrial Manual, Chapter 2.1.5. Foot and mouth disease. 1-29

Knowles NJ, Samuel AR (2003). Molecular epidemiology of foot-and-mouth disease virus. VirusResearch, 91: 65-80

Shimizu,N;Fukuzono S, Nishimura, N;Odawara Y;Fujiwara, K (1987) Cultivation of Escherichia coli harbouring hybrid plasmids. J Ferment Technol 65:7-10

Sambrook,,J.; Fritsch, E.F.;Maniatis, T (1989). "Molecular Cloning": A Laboratory Manual Cold Spring Harbor Laboratory, Cold Spring Harbor New York.2:695-698

\footnotetext{
"تأسيس ومعايرة التعبير الجيني للجين المخلق اصطناعيا باستخدام جين الغلاف البروتيني لفيروس مرض الحمي القلاعية"

مرض الحمى القلاعية هو مرض حاد العدوى يصيب الحيوانات ذات الظلف المشقوق. وهناك سبعة أنماط مصلية من فيروس الحمى القلاعية ، SAT1،

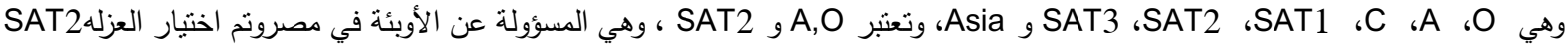

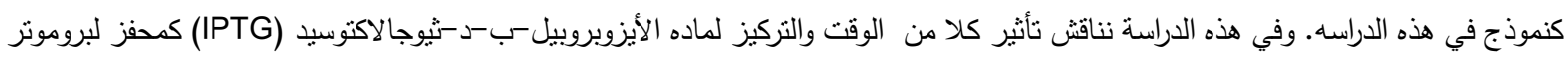
التاك دنا المنتج صناعيا ، وفي الزراعات صغيرة النطاق ثبت جيدا لأكثر من التعبير الجيني باستخدام الجين الاصطناعى من جين الغطاء لفيروس

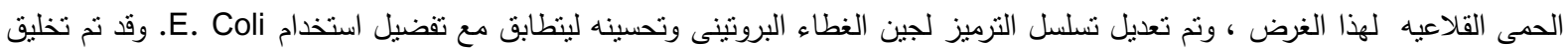

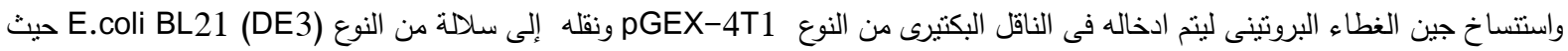

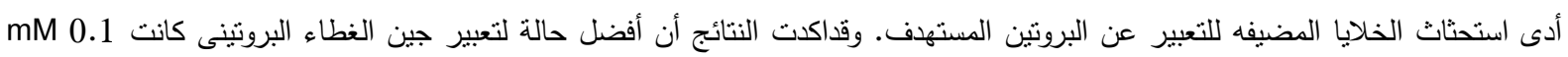
عند درجه حراره 16 درجة مئوية طوال الليل. وتم تحليل البروتين المعبر عن طريق SDS-PAGE ورجود شريط يحتوي على كتلة جزيئية

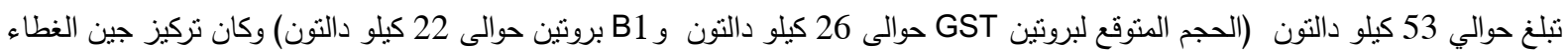
البرونينى المؤتلف هو 1 ملى جرام لكل 100ملى من المزرعة .
} 